\title{
The Impact of Coworker and Supervisor Support on Stress among Malaysian School Teachers during the COVID-19 Pandemic
}

\author{
Lin Dar Ong* ${ }^{*}$ and Faizul Adib bin Sulaiman Khan \\ Universiti Malaya, Kuala Lumpur, Malaysia
}

\begin{abstract}
In the current COVID-19 crisis, teaching is difficult. The demands from students, parents, the government, and school administrators may be overwhelming. Many Malaysian teachers are experiencing growing mental strain, and they are reluctant to seek help due to social stigma. This quantitative study explored the impact of coworker and supervisor support on stress among primary and secondary school teachers in Malaysia. In addition, the study examined the spill-over impact of stress on teachers' turnover intention. A sample of 250 Malaysian school teachers completed a questionnaire. The data were analysed using correlation and regression analyses. Results re-emphasized the positive impact of coworker support on reducing teachers' stress, but not supervisor support. Furthermore, it was found that teacher stress was linked to a higher likelihood of turnover. Therefore, it is important for school administrators and policymakers to strengthen the role of coworkers in reducing stress among Malaysian school teachers.
\end{abstract}

Keywords: coworker support; Malaysian school teachers; stress; supervisor support; turnover intention

\section{Introduction}

Teaching is a noble profession that demands a great deal of patience and resilience. Among the stressors that school teachers typically face are student achievement, professional development, disciplinary issues, overcrowded classes, involuntary transfers, extensive admin and paperwork, low pay, demanding or unsupportive parents, and a lack of administrative assistance (Fernández-Batanero et al., 2021; Russell et al., 1987). The stress undisputedly affects many teachers, regardless of their qualifications. Many studies have reported an increase in cases involving poor well-being among school teachers. For example, the Teaching and Learning International Survey (TALIS) conducted

\footnotetext{
* Corresponding author: Lin Dar Ong, lindar@um.edu.my
} 
by the Organisation for Economic Co-operation and Development (OECD) in 2018 covered over 260,000 teachers in 15,000 schools in 48 countries. Results of the survey revealed that $18 \%$ of teachers experienced a lot of stress at work, and $49 \%$ felt that having too much administrative work to do is one of the main sources of stress (OECD, 2018). This demonstrates that teachers spend a substantial amount of time on non-teaching tasks, and this could drive the higher stress levels among teachers. A study conducted by the Ministry of Education Malaysia in 2017 revealed that 2123 or $4.4 \%$ of teachers experienced moderate stress levels (Radhi, 2018). According to former Malaysian Minister of Education Dr Mazlee Malik, teachers in Malaysia are under increasing emotional strain because of personal problems, financial difficulties, job insecurity, living apart from their families, and meeting demands from students, parents, and school heads (Rajaendram, 2019).

Due to the COVID-19 pandemic, individuals all around the world faced a sudden change in their job roles (Vaziri et al., 2020). The lockdowns in response to the pandemic have interrupted conventional schooling, with nationwide school closures in many countries. Measures were quickly put into place, which included social distancing (i.e., keeping 6 feet apart), wearing masks, washing hands, and travel restrictions to combat the spread of the virus. The pandemic has posed many unprecedented challenges to the responsibilities of teachers. Teaching is becoming more stressful. The drastic shift from in-person learning to online learning has caused stress among teachers, parents, and students (Chandra, 2020). Teachers have to stay current with technology in order to present lessons remotely and respond to student complaints about inadequate internet connections or a lack of appropriate tools and devices. Furthermore, some teachers may have several duties, such as home-schooling their children, caring for elderly relatives, and maintaining their own mental health. Teachers may find themselves in a very stressful scenario as a result of the combination of these factors.

The announcement of a movement control order due to the COVID-19 crisis in March 2020 forced school lessons in Malaysia to be moved online. Although schools had reopened in stages by June 24, 2020, the Ministry of Education Malaysia introduced comprehensive standard operating procedures and social distancing rules to be implemented across all schools nationwide. Schools were closed again in October 2020 when the third wave hit Malaysia. Throughout the year 2020, schools in Malaysia were opened for face-to-face learning for only about five to six months. The school closures affected more than 5 million students and 440,684 teachers from 10,713 schools in Malaysia (Unesco, 2020). The stress associated with the teaching profession during the COVID-19 pandemic can lead to both emotional and physical exhaustion. We believe excessive stress will ultimately lead to shortages of high-quality teachers.

How teachers cope with stress and the day-to-day functions of their jobs are important considerations as the impact can be seen not only on the individual teacher but also on student outcomes (Herman et al., 2018). In their study among elementary school teachers, Herman et al. (2018) found that $93 \%$ of their sample fell into categories with high levels of stress (i.e., stressed/low coping [3\%], stressed/moderate coping [30\%], and stressed/high coping [60\%]). There was a 
correlation between those teachers that fell into the stressed and low-coping category and more disruptive behaviours in class and lower student achievement. Other similar studies have also shown that teachers who experience high levels of burnout are linked to poor performance, low self-efficacy, lower job satisfaction, and a higher attrition rate (Herman et al., 2018; Taylor et al., 2021). As a result, we believe there must be a right balance between school quality assurance and ensuring that teachers are not overworked.

In industrialized countries, people are becoming more aware of and increasingly familiar with work-related stress and stress management. However, that is not the case in developing countries, where mental health is often neglected. Besides, research on stress and well-being among teachers in Malaysia is rather limited. In Malaysia, the data from the National Health and Morbidity Survey (NHMS) in 2019 revealed that approximately half a million Malaysian adults are suffering from depression symptoms (Malaysia. Institute for Public Health, 2020). Mental healthcare received RM344.82 million in the Malaysia Budget 2020, which is less than $1 \%$ of the national health budget. This was less than the $2.8 \%$ global average (Bernama, 2020). Amidst a surge in COVID-19 cases in Malaysia, the funding was lowered by $9.1 \%$ to RM313 million in 2021. Therefore, there is a need to examine the well-being of teachers in Malaysia during the pandemic.

Previous studies have shown that coworker support may alleviate stress among employees. For example, Tews et al. (2013) found that coworker support could reduce stress and burnout for servers at a restaurant chain. Furthermore, supervisor support has a central impact on teachers' experience and well-being in the workplace (Burger et al., 2021; Kahn et al., 2006; Tevfik \& Ozdem, 2017). Thus, it is expected that support from coworkers and supervisors is important for alleviating stress among teachers, especially during the pandemic. Because the influence of coworker and supervisor support during the COVID-19 pandemic on teachers' job stress is unknown, we explore whether the social support is associated with stress among teachers and whether it thereby affects their turnover intention.

Taking cue from the above conditions, this study seeks to raise awareness of the importance of coworker and supervisor support in the workplace in reducing stress among Malaysian teachers during the COVID-19 crisis. This study also seeks to establish a relationship between teachers' stress and turnover intention. Finally, this research will contribute to filling gaps in the literature pertaining to mental health issues among Malaysian school teachers.

\section{Literature Review}

Literature has associated social support with the extent to which a job provides possibilities for seeking help and guidance from supervisors or coworkers, as well as friendship opportunities on the job (Karasek et al., 1998; Sims et al., 1976). According to the Conservation of Resources Model, social support is especially helpful in dealing with stress and burnout (Hobfoll, 1989; Hobfoll et al., 2018). People with high degrees of social support have more opportunity to get advice and help from others. Individuals tend to feel cared for and valued when they 
receive help from others, and this may mitigate the negative effects of stress (Baruch-Feldman et al., 2002). Therefore, social support from both coworkers and supervisors is needed for teachers to perform their tasks effectively.

The role of supervisor support in reducing employees' perceived uncertainty and emotional exhaustion during the COVID-19 crisis can be explained theoretically through social support theory, which suggests that social support protects people from the negative effects of stressful events (Shumaker \& Brownell, 1984). In addition to social support theory, the JD-R model of work stress can explain the role of social support in reducing emotional exhaustion (Bakker \& Demerouti, 2007). According to the model, employees' stress perception can be reduced when they have adequate job resources, such as social support, to deal with job demands. As the nature of teaching often implies intense emotional experiences, support from school administrators/supervisors and coworkers would allow teachers to share their thoughts and feelings, thereby reducing stress (Howard \& Johnson, 2004). Chang (2009) found that working in schools that lack social support from colleagues and administration is one of the job characteristics that has been related to burnout among teachers. Thus, appropriate social support may help school teachers cope with a hectic workload.

The OECD 2018 TALIS reported that those who have good relationships with their colleagues have higher levels of well-being at work and in life in general (OECD, 2018). Halbesleben (2006) found that emotional weariness was strongly connected to social support from coworkers and superiors. Therefore, social support from coworkers and supervisors may influence the stress levels among school teachers.

According to previous studies, teachers who receive more support from their leaders have better work satisfaction and a greater sense of personal accomplishment, and are less likely to suffer from burnout (Baroudi et al., 2020; Brackett et al., 2010). In contrast, Greenglass et al. (1997) discovered that among teachers in Canada, coworker support is the most essential buffer against emotional weariness among three kinds of social support (i.e., the teacher's supervisor, coworkers, and friends and family). Therefore, there are mixed results with regard to the source of social support in reducing teacher stress.

Although it has been discovered that social support from coworkers and superiors is crucial in reducing undesirable consequences such as workplace stress (Karasek et al., 1998; Mayo et al., 2012), previous studies have investigated these two sources of support separately (Kristof-Brown et al., 2005). For example, in a study in Thailand, Charoensukmongkol and Phungsoonthorn (2021) examined the role supervisor support played during the COVID-19 crisis in alleviating the negative effects of job demands caused by the uncertainties. The authors found that supervisor support helps university lecturers and staff members in dealing with the stress caused by uncertainties due to the pandemic. As a result, the purpose of this study is to look at the impact of social support from various sources (supervisors and coworkers) on Malaysian school teachers' stress during the COVID-19 pandemic. Recent research has demonstrated that fear of COVID-19 has a detrimental impact on employees' mental health and well-being (Bakioğlu 
et al., 2021; Satici et al., 2020). Social support from both supervisors and coworkers may help teachers to alleviate stress. Therefore, we formulated the following hypotheses:

Hypothesis 1: Coworker support is negatively related to teachers' job stress.

Hypothesis 2: Supervisor support is negatively related to teachers' job stress.

Teacher turnover represents one of the most pressing issues in many schools. Teacher turnover has been linked to a slew of major issues, including reduced instructional staff quality and worse student success (Henry \& Redding, 2020; Ronfeldt et al., 2013; Sorensen \& Ladd, 2020). When an employee quits the company, the money and effort spent on employing and training them are irrevocably gone. For example, Waldman et al. (2004) revealed that for 2001, the medical industry's minimal cost of turnover amounted to a loss of more than $5 \%$ of the whole annual operating budget.

In a survey by the U.S. Department of Education in 2015, among all the teachers who began teaching in calendar year $2007 / 2008,10 \%$ quit in $2008 / 2009$, an additional $12 \%$ did not teach in 2009/2010, 15\% did not teach in 2010/2011, and another 17\% did not teach in 2011/2012 (Gray \& Taie, 2015). Consequently, over the last five years, $22 \%$ of teachers quit before their third year and $54 \%$ quit within the first five years of teaching.

According to Liu and Onwuegbuzie (2012), 40.4\% of Chinese teachers would leave teaching for another career if the chance occurred. They discovered that a high degree of stress was the primary cause for Chinese teachers' intention to leave. In contrast to developed countries such as the United States, very little research has been done on teacher stress and employment decisions in developing countries such as Malaysia (Zembylas \& Papanastasiou, 2004). Thus, this study aims to examine the negative effects of stress on school teachers in Malaysia.

According to early research, turnover intention is linked to actual turnover (cf. Tett \& Meyer, 1993; Tran et al., 2020). Many businesses would rather know their employees' intention to leave than the actual turnover rate, so they may take proactive measures to keep them from leaving. As a result, this study focuses on the intention of turnover rather than the actual turnover of school teachers. Stress could adversely affect Malaysian teachers and they may want to leave their jobs. We thus formulated a third hypothesis:

Hypothesis 3: Teachers' job stress is positively related to turnover intention.

A summary of the proposed relationships under investigation can be found in Figure 1.

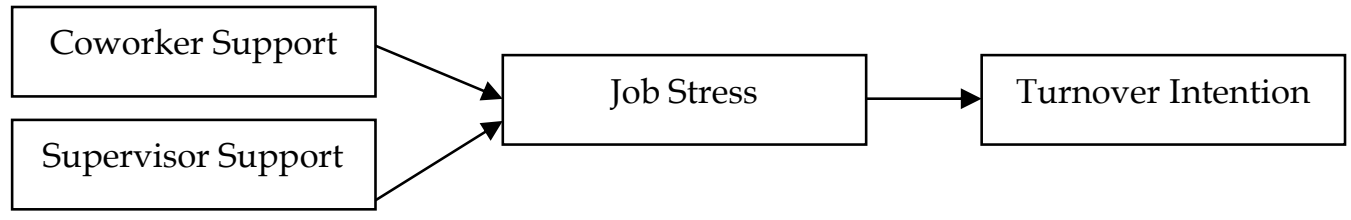

Figure. 1: Research model: Relationships between coworker support, supervisor support, job stress, and turnover intention 


\section{Method}

\subsection{Participants}

Of the 250 teachers that participated in this study, $180(72 \%)$ were female and $70(28 \%)$ were male. The majority of the respondents were Malays $(90 \%)$ and had a bachelor's degree $(77 \%)$. Regarding age, $42 \%$ of the sample were between the ages of 40 and 49 . Lastly, $28 \%$ of respondents had 11 to 15 years of teaching experience.

\subsection{Data Collection Tools}

In this study, we collected the data using a quantitative field study. The questionnaire survey was generated using Google Forms and distributed online using social media apps and emails to school teachers in Klang Valley (Kuala Lumpur and Selangor), Malaysia. The questionnaire survey had five sections, consisting of the demographic profile of respondents, their views on coworker support, supervisor support, and job stress, respectively, as well as their turnover intention. The cover letter in the questionnaire that introduced the research to the respondents stressed that participation was completely voluntary. To enhance participation, pre-announcements and reminder notifications were sent to respondents. Of the 300 questionnaires administered, 250 were returned.

\subsection{Measures}

The measurement items were developed from previous studies and were distributed online to respondents via Google Forms. All items were graded on a seven-point Likert scale. The four main measurements are discussed next.

Stress. To capture respondents' stress levels at work, we used the scale originally created by Parker and DeCotiis (1983) and later shortened to nine items by Jamal and Baba (1992). The following are examples of sample items: "There are lots of times when my job drives me right up a wall," and "I sometimes dread the telephone ringing at home because the call might be job-related." The Cronbach alpha for the scale was .75.

Coworker support. We evaluated the extent to which respondents believed their coworkers are supportive using a nine-item scale from Ladd and Henry (2000). Among the items were: "Help is available from my coworkers when I have a problem," "My coworker really cares about my well-being," and "My coworkers are willing to offer assistance or to help me perform my job to the best of my ability." The Cronbach alpha was .94 .

Supervisor support. With four questions from the Survey of Perceived Organizational Support, we assessed respondents' perceptions of how supportive their supervisors are (Rhoades et al., 2001). A sample item is: "My work supervisor really cares about my well-being." The Cronbach alpha was .92.

Turnover intention. Respondents' intention to leave their employment was measured using a four-item scale (De Clercq et al., 2020). The items were applied by De Clercq et al. (2020) from past studies (Bluedorn, 1982; Jones et al., 2007; Saeed et al., 2014). The following are some examples of sample items: "I often 
think about quitting" and "It is likely that I will actively look for a new job next year." The Cronbach alpha was .81.

\section{Results}

Pearson's correlation was calculated to examine the correlations among coworker support, supervisor support, job stress, and turnover intention. The means, standard deviations, and correlations among the variables in the study are depicted in Table 1. As expected, both coworker and supervisor support negatively correlated with stress $(r=-.127$ and $r=-.055$, respectively). In addition, stress was positively correlated with turnover intention $(\mathrm{r}=.424)$.

Table 1: Correlations, means, standard deviations, and reliability

\begin{tabular}{|l|l|l|l|l|l|l|}
\hline Variable & $\mathbf{M}$ & SD & $\mathbf{1}$ & $\mathbf{2}$ & $\mathbf{3}$ & $\mathbf{4}$ \\
\hline 1. Coworker support & 5.12 & 0.74 & $(0.77)$ & & & \\
\hline 2. Supervisor support & 4.88 & 0.86 & $.593^{* *}$ & $(0.53)$ & & \\
\hline 3. Job stress & 4.69 & 1.09 & $-.127^{*}$ & -.055 & $(0.87)$ & \\
\hline 4. Turnover intention & 3.03 & 1.53 & $-.183^{* *}$ & -.005 & $.424^{* *}$ & $(0.9)$ \\
\hline
\end{tabular}

Note. $\mathrm{M}=$ mean; $\mathrm{SD}=$ standard deviation; ${ }^{*} \mathrm{p}<.05 ;{ }^{* *} \mathrm{p}<.01$. Reliabilities in parentheses diagonally.

The descriptive statistics for each quantitative variable are presented in Table 1. The coefficient alphas for coworker support, job stress, and turnover intention were above $0.75(0.77,0.87$, and 0.9 , respectively). For the supervisor support scale, the internal consistency was less satisfactory $(0.53)$.

Multiple regression analysis was run to investigate whether coworker support and supervisor support are significant in relation to stress, and whether stress is significantly related to turnover intention. Table 2 presents the multiple regression results of all independent variables in relation to job stress, whereas Table 3 presents the findings of the multiple regression analysis of job stress and turnover intention.

Table 2: Multiple regression: Coworker support, supervisor support, and job stress among Malaysian teachers $(\mathrm{N}=250)$

\begin{tabular}{|l|l|l|l|}
\hline & Job stress & $\beta$ \\
\hline & B & SE & $.15^{*}$ \\
\hline Coworker support & .22 & .12 & -.04 \\
\hline Supervisor support & -.05 & .10 & .
\end{tabular}

Note. $\mathrm{B}=$ unstandardized regression coefficient; $\mathrm{SE}=$ standard error of the coefficient; $\beta=$ standardized coefficient; ${ }^{*} p<.05 ;{ }^{* *} p<.01$.

Table 2 shows that coworker support is significantly related to job stress $(\beta=.15$, $p<.05)$. However, supervisor support is not related to job stress $(\beta=-.04, p>.05)$. Therefore, $\mathrm{H} 1$ is supported, whereas $\mathrm{H} 2$ is not supported. 
Table 3: Multiple regression: Job stress and turnover intention among Malaysian teachers $(\mathbf{N}=\mathbf{2 5 0})$

\begin{tabular}{|l|l|l|l|}
\hline & \multicolumn{3}{|l|}{ Turnover intention } \\
\hline & B & SE & $\beta$ \\
\hline Job stress & .60 & .08 & $.42^{\star *}$ \\
\hline
\end{tabular}

Note. $\mathrm{B}=$ unstandardized regression coefficient; $\mathrm{SE}=$ standard error of the coefficient; $\beta=$ standardized coefficient; ${ }^{*} p<.05 ;{ }^{* *} p<.01$.

Table 3 shows that job stress is significantly related to turnover intention $(\beta=.42$, $p<.01)$. This finding therefore supports H3.

\section{Discussion}

This study explored the impact of coworker and supervisor support on Malaysian school teachers' levels of stress and how stress affects teachers' turnover intention. We started by examining the direct impact of coworker and supervisor support on a teacher's job stress via the first regression analysis. We established that coworker support had a direct impact on teachers' stress, but supervisor support did not. Greenglass et al. (1997) observed that stronger coworker support related to the prediction of burnout among Canadian teachers. Chen and Ye (2021) also discovered that teachers' attitudes about administrative assistance have an impact on their job satisfaction. Similarly, Van Droogenbroeck et al. (2014) discovered that peer support helps protect teachers from burnout. As Beehr (1985) suggested, coworker contact provides more emotional support, such as friendship and comfort, which helps a worker cope with existing stressors. In addition, Cappe et al. (2021) found that social support from coworkers has an impact on individuals' stress. The results may imply the importance of coworker support in reducing stress among Malaysian school teachers. Contrary to previous findings, this study found that supervisor support did not have an impact on teachers' stress. This may be because teachers need more emotional support amidst the COVID 19 crisis, and they tend to receive that kind of support from someone closer to them, such as coworkers, rather than their supervisors.

Next, we established through the second regression analysis that teachers' stress had a direct impact on turnover intention. The finding is consistent with those of studies conducted by Liu and Onwuegbuzie (2012) in China, and Lee (2019) in the United States. When employees are emotionally exhausted or burned out, they are more likely to leave their current jobs (Moore, 2000; Said et al., 2021).

This study has several important implications. The results indicate that teachers would be able to deal with their job stress if they received help and support from their colleagues. Not only should teachers seek assistance from others in the workplace, coworkers should approach workers they suspect may be experiencing stress in order to help them alleviate stress. As suggested by De Clercq et al. (2020), coworker support has a stress-reducing effect as it diminishes employee turnover intention due to reduced job stress. Employees who believe that coworkers care about their well-being and go out of their way to help them tend to get positive energy from their interactions with colleagues, and therefore are less likely to look for alternative employment (Bufquin et al., 2017). As a result, school officials and the government should work together to develop 
a system in which teachers may support, assist, and care for one another. Since we found that teachers' job stress had a significant relationship with turnover intention, school administrators and policymakers should provide help to teachers to manage stress effectively. Even though teachers may not quit their jobs even if they have such intention, turnover intention does indicate their dissatisfaction with the current job. Future studies should explore positive psychology interventions in relation to the well-being and mental health of Malaysian school teachers. The impact of enhanced teacher well-being on pupils when they are supported in the sense of positive psychology is another intriguing area for additional investigation.

\section{Limitations}

Although this study provides some important information about teacher mental health in Malaysia, it does have some drawbacks. First, the scales were measured through respondent self-report, which might have restricted the accuracy of the replies due to bias (Latkin et al., 2017). Second, this research was conducted in a cross-sectional manner. Longitudinal studies would be useful to identify the causality of the relationships examined and to develop interventions.

\section{Conclusion}

The Ministry of Education Malaysia has hired more counselors to help teachers deal with the job-related stress they face. However, the mental health and quality of life among Malaysian teachers remain challenging. This study explored the role of coworkers and supervisors in reducing Malaysian school teachers' stress levels. It was found that coworker support had a significant impact on teachers' stress levels, whereas supervisor support did not. In addition, job stress was found to be significantly related to teachers' turnover intention. Findings may imply a strong link between coworker support and positive psychology and a need for further research into positive psychology. Furthermore, intervention studies to look at the impact of engagement, motivation, self-compassion, and well-being on the mental health of Malaysian teachers seem to be necessary.

\section{References}

Bakioğlu, F., Korkmaz, O., \& Ercan, H. (2021). Fear of COVID-19 and positivity: Mediating role of intolerance of uncertainty, depression, anxiety, and stress. International Journal of Mental Health and Addiction, 19, 2369-2382. https://doi.org/10.1007/s11469-020-00331-y

Bakker, A. B., \& Demerouti, E. (2007). The Job Demands-Resources Model: State of the art. Journal of Managerial Psychology, 22(3), 309-328. https://doi.org/10.1108/02683940710733115

Baroudi, S., Tamim, R., \& Hojeij, Z. (2020). A quantitative investigation of intrinsic and extrinsic factors influencing teachers' job satisfaction in Lebanon. Leadership and Policy in Schools, 1-20. https:/ / doi.org/10.1080/15700763.2020.1734210

Baruch-Feldman, C., Brondolo, E., Ben-Dayan, D., \& Schwartz, J. (2002). Sources of social support and burnout, job satisfaction, and productivity. Journal of Occupational Health Psychology, 7(1), 84-93. https:/ / doi.org/10.1037/1076-8998.7.1.84

Beehr, T. A. (1985). The role of social support in coping with organizational stress. In T. A. Beehr \& R. S. Bhagat (Eds.), Human stress and cognition in organizations: An integrated perspective (pp. 375-398). Wiley.

Bernama (2020, October 10). Survey finds almost half a million Malaysians experience 
symptoms of depression. astro Awani. https://www.astroawani.com/beritamalaysia/survey-finds-almost-half-million-malaysians-experience-symptomsdepression-262944

Bluedorn, A. C. (1982). A unified model of turnover from organizations. Human Relations, 35(2), 135-153. https://doi.org/10.1177/001872678203500204

Brackett, M. A., Palomera, R., Mojsa-Kaja, J., Reyes, M. R., \& Salovy, P. (2010). Emotion-regulation ability, burnout, and job satisfaction among British secondary-school teachers. Psychology in the Schools, 47(4), 406-417. https://doi.org/10.1002/pits.20478

Bufquin, D., DiPietro, R., Orlowski, M., \& Partlow, C. (2017). The influence of restaurant co-workers' perceived warmth and competence on employees' turnover intentions: The mediating role of job attitudes. International Journal of Hospitality Management, 60, 13-22. https://doi.org/10.1016/j.ijhm.2016.09.008

Burger, J., Bellhäuser, H., \& Imhof, M. (2021). Mentoring styles and novice teachers' well-being: The role of basic need satisfaction. Teaching and Teacher Education, 103, 103345. https://doi.org/10.1016/j.tate.2021.103345

Cappe, E., Poirier, N., Engelberg, A., \& Boujut, E. (2021). Comparison of teachers in France and in Quebec working with autistic students: Self-efficacy, stress, social support, coping, and burnout. Teaching and Teacher Education, 98, 103244. https://doi.org/10.1016/j.tate.2020.103244

Chandra, Y. (2020). Online education during COVID-19: Perception of academic stress and emotional intelligence coping strategies among college students. Asian Education and Development Studies, 10(2), 229-238. https://doi.org/10.1108/aeds-05-20200097

Chang, M. L. (2009). An appraisal perspective of teacher burnout: Examining the emotional work of teachers. Educational Psychology Review, 21(3), 193-218. https://doi.org/10.1007/s10648-009-9106-y

Charoensukmongkol, P., \& Phungsoonthorn, T. (2021). The effectiveness of supervisor support in lessening perceived uncertainties and emotional exhaustion of university employees during the COVID-19 crisis: The constraining role of organizational intransigence. The Journal of General Psychology, 148(4), 431-450. https://doi.org/10.1080/00221309.2020.1795613

Chen, Y., \& Ye, Y. (2021). The relationship between teachers' perception towards administrative support and their job satisfaction in a secondary vocational school, Kunming, China. Scholar: Human Sciences, 13(1), 91-104. http://www.assumptionjournal.au.edu/index.php/Scholar/article/view/4363

De Clercq, D., Azeem, M. U., Haq, I. U., \& Bouckenooghe, D. (2020). The stress-reducing effect of coworker support on turnover intentions: Moderation by political ineptness and despotic leadership. Journal of Business Research, 111, 12-24. https://doi.org/10.1016/j.jbusres.2020.01.064

Fernández-Batanero, J. M., Román-Graván, P., Reyes-Rebollo, M. M., \& MontenegroRueda, M. (2021). Impact of educational technology on teacher stress and anxiety: A literature review. International Journal of Environmental Research and Public Health, 18(2), 548. https:// doi.org/10.3390/ijerph18020548

Gray, L., \& Taie, S. (2015). Public school teacher attrition and mobility in the first five years: Results from the first through fifth waves of the 2007-08 beginning teacher longitudinal study. U.S. Department of Education, National Center for Education Statistics. https://nces.ed.gov/pubs2015/2015337.pdf

Greenglass, E. R., Burke, R. J., \& Konarski, R. (1997). The impact of social support on the development of burnout in teachers: Examination of a model. Work \& Stress, 11(3), 267-278. https:// doi.org/10.1080/02678379708256840

Halbesleben, J. R. B. (2006). Sources of social support and burnout: A meta-analytic test of the conservation of resources model. Journal of Applied Psychology, 91, 1134-1145. 
https:// doi.org/10.1037/0021-9010.91.5.1134

Henry, G. T., \& Redding, C. (2020). The consequences of leaving school early: The effects of within-year and end-of-year teacher turnover. Education Finance and Policy, 15(2), 332-356. https://doi.org/10.1162/edfp_a_00274

Herman, K. C., Hickmon-Rosa, J. E., \& Reinke, W. M. (2018). Empirically derived profiles of teacher stress, burnout, self-efficacy, and coping and associated student outcomes. Journal of Positive Behavior Interventions, 20(2), 90-100. https://doi.org/10.1177/1098300717732066

Hobfoll, S. E. (1989). Conservation of resources: A new attempt at conceptualizing stress. American Psychologist, 44(3), 513-524. https://doi.org/10.1037/0003-066x.44.3.513

Hobfoll, S. E., Halbesleben, J., Neveu, J. P., \& Westman, M. (2018). Conservation of resources in the organizational context: The reality of resources and their consequences. Annual Review of Organizational Psychology and Organizational Behavior, 5, 103-128. https://doi.org/10.1146/annurev-orgpsych-032117-104640

Howard, S., \& Johnson, B. (2004). Resilient teachers: Resisting stress and burnout. Social Psychology of Education: An International Journal, 7(4), 399-420. https://doi.org/10.1007/s11218-004-0975-0

Jamal, M., \& Baba, V. V. (1992). Shiftwork and department-type related to job stress, work attitudes and behavioral intentions: A study of nurses. Journal of Organizational Behavior, 13(5), 449-464. https://doi.org/10.1002/job.4030130503

Jones, E., Chonko, L., Rangarajan, D., \& Roberts, J. (2007). The role of overload on job attitudes, turnover intentions, and salesperson performance. Journal of Business Research, 60(7), 663-671. https://doi.org/10.1016/j.jbusres.2007.02.014

Kahn, J. H., Schneider, K. T., Jenkins-Henkelman, T. M., \& Moyle, L. L. (2006). Emotional social support and job burnout among high-school teachers: Is it all due to dispositional affectivity? Journal of Organizational Behavior, 27(6), 793-807. https://doi.org/10.1002/job.397

Karasek, R., Brisson, C., Kawakami, N., Houtman, I., Bongers, P., \& Amick, B. (1998). The Job Content Questionnaire (JCQ): An instrument for internationally comparative assessments of psychosocial job characteristics. Journal of Occupational Health Psychology, 3(4), 322-355. https:// doi.org/10.1037/1076-8998.3.4.322

Kristof-Brown, A. L., Zimmerman, R. D., \& Johnson, E. C. (2005). Consequences of individuals' fit at work: A meta-analysis of person-job, person-organization, person-group, and person-supervisor fit. Personnel Psychology, 58(2), 281-342. https://doi.org/10.1111/j.1744-6570.2005.00672.x

Ladd, D., \& Henry, R. A. (2000). Helping coworkers and helping the organization: The role of support perceptions, exchange ideology, and conscientiousness. Journal of Applied Social Psychology 30(10), 2028-2049. https://doi.org/10.1111/j.15591816.2000.tb02422.x

Latkin, C. A., Edwards, C., Davey-Rothwell, M. A., \& Tobin, K. E. (2017). The relationship between social desirability bias and self-reports of health, substance use, and social network factors among urban substance users in Baltimore, Maryland. Addictive Behaviors, 73, 133-136. https://doi.org/10.1016/j.addbeh.2017.05.005

Lee, Y. H. (2019). Emotional labor, teacher burnout, and turnover intention in high-school physical education teaching. European Physical Education Review, 25(1), 236-253. https://doi.org/10.1177/1356336X17719559

Liu, S., \& Onwuegbuzie, A. J. (2012). Chinese teachers' work stress and their turnover intention. International Journal of Educational Research, 53, 160-170. https://doi.org/10.1016/j.ijer.2012.03.006

Malaysia. Institute for Public Health. (2020). National Health and Morbidity Survey (NHMS) 2019: Non-communicable diseases, healthcare demand, and health literacy - Key findings. https://iptk.moh.gov.my/images/technical_report/2020/4_Infographic_Bookle t_NHMS_2019_-_English.pdf 
Mayo, M., Sanchez, J. I., Pastor, J. C., \& Rodriguez, A. (2012). Supervisor and coworker support: A source congruence approach to buffering role conflict and physical stressors. The International Journal of Human Resource Management, 23(18), 3872-3889. https://doi.org/10.1080/09585192.2012.676930

Moore, J. E. (2000). Why is this happening? A causal attribution approach to work exhaustion consequences. Academy of Management Review, 25(2), 335-349. https://doi.org/10.2307/259017

Organisation for Economic Co-operation and Development (OECD). (2018). 2018 TALIS results: Teachers and school leaders as lifelong learners and valued professionals. https://www.oecd.org/education/talis/

Parker, D. F., \& DeCotiis, T. A. (1983). Organizational determinants of job stress. Organizational Behavior \& Human Performance, 32(2), 160-177. https://doi.org/10.1016/0030-5073(83)90145-9

Radhi, N. A. M. (2018, August 28). 4.4 per cent of teachers experienced moderate stress level last year. New Strait Times. https://www.nst.com.my/news/nation/2018/08/405754/44-cent-teachersexperienced-moderate-stress-level-last-year

Rajaendram, R. (2019, July 4). Teachers facing more mental pressure. The Star. https://www.thestar.com.my/news/education/2019/07/14/teachers-facingmore-mental-pressure

Rhoades, L., Eisenberger, R., \& Armeli, S. (2001). Affective commitment to the organization: The contribution of perceived organizational support. Journal of Applied Psychology, 86(5), 825-836. https:// doi.org/10.1037/0021-9010.86.5.825

Ronfeldt, M., Loeb, S., \& Wyckoff, J. (2013). How teacher turnover harms student achievement. American Educational Research Journal, 50(1), 4-36. https://doi.org/10.3102/0002831212463813

Russell, D. W., Altmaier, E., \& Van Velzen, D. (1987). Job-related stress, social support, and burnout among classroom teachers. Journal of Applied Psychology, 72(2), 269-274. https:// doi.org/10.1037/0021-9010.72.2.269

Saeed, I., Waseem, M., Sikander, S., \& Rizwan, M. (2014). The relationship of turnover intention with job satisfaction, job performance, leader member exchange, emotional intelligence and organizational commitment. International Journal of Learning and Development, 4(2), 242-256. https:// doi.org/10.5296/ijld.v4i2.6100

Said, H., Ali, L., Ali, F., \& Chen, X. (2021). COVID-19 and unpaid leave: Impacts of psychological contract breach on organizational distrust and turnover intention: Mediating role of emotional exhaustion. Tourism Management Perspectives, 39, 100854. https://doi.org/10.1016/j.tmp.2021.100854

Satici, B., Saricali, M., Satici, S. A., \& Griffiths, M. D. (2020). Intolerance of uncertainty and mental wellbeing: Serial mediation by rumination and fear of COVID-19. International Journal of Mental Health and Addiction. https:// doi.org/10.1007/s11469-020-00305-0

Shumaker, S. A., \& Brownell, A. (1984). Toward a theory of social support: Closing conceptual gaps. Journal of Social Issues, 40(4), 11-36. https://doi.org/10.1111/j.1540-4560.1984.tb01105.x

Sims, H. P., Szilagyi, A. D., \& Keller, R. T. (1976). The measurement of job characteristics. Academy of Management Journal, 19, 195-212. https://doi.org/10.2307/255772

Sorensen, L. C., \& Ladd, H. F. (2020). The hidden costs of teacher turnover. AERA Open, 6(1), 2332858420905812. https:// doi.org/10.1177/2332858420905812

Taylor, S. G., Roberts, A. M., \& Zarrett, N. (2021). A brief mindfulness-based intervention (bMBI) to reduce teacher stress and burnout. Teaching and Teacher Education, 100, 103284. https:// doi.org/10.1016/j.tate.2021.103284

Tett, R. P., \& Meyer, J. P. (1993). Job satisfaction, organizational commitment, turnover intention, and turnover: Path analyses based on meta-analytic findings. Personnel 
Psychology, 46(2), 259-293. https://doi.org/10.1111/j.1744-6570.1993.tb00874.x

Tevfik, U., \& Ozdem, G. (2017). The mediating role of job satisfaction on the relationship between teachers perceptions of supervisor support and job performances. International Journal of Educational Administration and Policy Studies, 9(7), 84-90. https://doi.org/10.5897/ijeaps2017.0519

Tews, M. J., Michel, J. W., \& Ellingson, J. E. (2013). The impact of coworker support on employee turnover in the hospitality industry. Group and Organization Management, 38(5), 630-653. https://doi.org/10.1177/1059601113503039

Tran, K. T., Nguyen, P. V., Nguyen, T. D., \& Ton, U. N. H. (2020). The impact of organisational commitment on the relationship between motivation and turnover intention in the public sector. International Journal of Innovation, Creativity and Change, 11(12), 1-25.

https://www.ijicc.net/images/vol11iss12/111201_Tran_2020_E_R.pdf

Unesco. (2020). COVID-19 education response policy. https://en.unesco.org/sites/default/files/proceeding_of_sub_regional_webina r_on_covid_19_education_response_policy.pdf

Van Droogenbroeck, F., Spruyt, B., \& Vanroelen, C. (2014). Burnout among senior teachers: Investigating the role of workload and interpersonal relationships at work. Teaching and Teacher Education, 43, 99-109. https://doi.org/10.1016/j.tate.2014.07.005

Vaziri, H., Casper, W. J., Wayne, J. H., \& Matthews, R. A. (2020). Changes to the work-family interface during the COVID-19 pandemic: Examining predictors and implications using latent transition analysis. Journal of Applied Psychology, 105(10), 1073-1087. https://doi.org/10.1037/ap10000819

Waldman, J. D., Kelly, F., Aurora, S., \& Smith, H. L. (2004). The shocking cost of turnover in health care. Health Care Management Review, 29(1), 2-7. https://doi.org/10.1097/00004010-200401000-00002

Zembylas, M., \& Papanastasiou, E. (2004). Job satisfaction among school teachers in Cyprus. Journal of Educational Administration, 42(3), 357-374.

http:/ / dx.doi.org/10.1108/09578230410534676 